\title{
(5)

\section{Oppdatert kunnskap om barn og ungdom i utsatte livssituasjoner}

ANMELDELSER

\section{PÅL ZEINER}

Overlege, Klinikk psykisk helse og avhengighet Oslo universitetssykehus

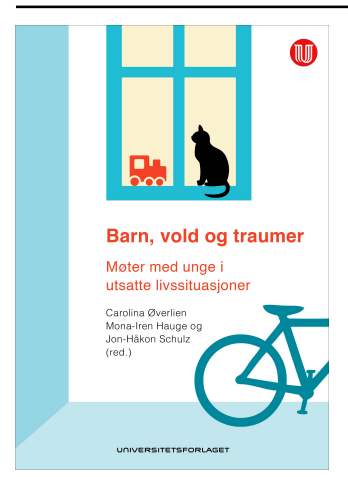

Carolina Øverlien, Mona-Iren Hauge, Jon-Håkon Schultzred.

Barn, vold og traumer

Møter med unge i utsatte livssituasjoner.308 s, ill. Oslo: Universitetsforlaget, 2016. Pris NOK 499

ISBN 978-82-15-02641-1

Nasjonalt kunnskapssenter om vold og traumatisk stress har vært sentral i forskningen og undervisningen om konsekvenser av opplevd vold og traumer. Forskerne har nå ønsket å gi en oppdatert kunnskap om barn og ungdom som har vært utsatt for ulike traumer, inklusive vold. Forskningen på dette feltet har skutt fart de siste årene, så boken dekker et behov for kunnskapsoppdatering for profesjonelle som kommer i kontakt med barn og ungdom i en utsatt livssituasjon.

Boken er bredt anlagt og dekker mange ulike områder. Den er delt inn i fire deler. I første del, Når katastrofen rammer, tar forfatterne for seg helseplager som følge av traumatiske hendelser, betydningen av foreldres reaksjoner, tidlig intervensjon, forebygging og utviklingsmessige perspektiver etter gjennomgått traume. Del 2, Å vokse opp med vold, har kapitler om å identifisere barn i utsatte livssituasjoner og prognostiske faktorer etter opplevd traume og ulike belastende livssituasjoner (vansker i samværsordning, ungdom med misbruk, minoritetsbakgrunn o.a.). I del 3 , Å hjelpe det utsatte barnet, omtales ulike aspekter $\mathrm{i}$ arbeidet med å hjelpe barn og ungdom i utsatte livssituasjoner, både gjennom generelle perspektiver og i omtale av spesifikke temaer om arbeid i skole, i barnevernet og 
med enslige unge flyktninger. I den siste delen, Metoder og perspektiver, tar forfatterne opp begrepsbruk, utviklingspsykologiske momenter og forskningsetiske utfordringer.

I alt har 19 forfattere med bakgrunn i medisin, psykologi, jus, pedagogikk og barnevern vært bidragsytere. Styrken ligger i at innholdet er bredt anlagt og dekker svært mange områder, alt fra råd til foreldre med delt omsorg for barn til ulike psykiatriske behandlingsmetoder for barn og ungdom med alvorlige reaksjoner etter traumer. Forfatterne vektlegger tidlig identifikasjon og forebygging, slik at kapitlet med fakta om mulige tegn på mishandling og råd for tidlig identifikasjon av utsatte barn, vurderes som spesielt relevant for leger.

Hvert kapittel står for seg. Det øker bredden i kunnskapstilfanget, men man kunne hatt noen oppsummerende kapitler omkring kartlegging, diagnostikk og behandling som kunne gjort boken enklere å bruke i en klinisk hverdag.

Alt i alt synes jeg at dette er en god oppdatering av nyere kunnskap om barn og unge i utsatte livssituasjoner. Boken er nyttig for mange yrkesgrupper som jobber innen helsetjeneste, sosialtjeneste, skole/barnehage og annet.

Publisert: 4. september 2017. Tidsskr Nor Legeforen. DOI: 10.4045/tidsskr.17.0418

(C) Tidsskrift for Den norske legeforening 2020. Lastet ned fra tidsskriftet.no 